\title{
Immunotherapy with VGX-3100 (HPV16 and HPV18 plasmids) + INO-9012 (DNA encoding IL-12) in human papillomavirus (HPV) associated head and neck squamous cell carcinoma (HNSCCa): interim safety and immunogenicity results
}

\author{
Charu Aggarwal ${ }^{1 *}$, Roger Cohen ${ }^{1}$, Matthew P Morrow², Joshua Bauml ${ }^{1}$, Gregory Weinstein ${ }^{1}$, Jean Boyer ${ }^{3}$, \\ Xuefei Shen ${ }^{3}$, Jian Yan², Jessica Goldenberg ${ }^{2}$, Drishty Nashit ${ }^{4}$, Sandra Oyola ${ }^{5}$, Jessica Lee ${ }^{4}$, Laurent M Humeau ${ }^{3}$, \\ David B Weiner ${ }^{1}$, Zane Yang ${ }^{5}$, Mark L Bagarazzi ${ }^{4}$, David Weiner ${ }^{1}$ \\ From 30th Annual Meeting and Associated Programs of the Society for Immunotherapy of Cancer (SITC 2015) \\ National Harbor, MD, USA. 4-8 November 2015
}

\section{Background}

Oropharyngeal HNSCCa is frequently associated with HPV infection. DNA-based Immunotherapy with plasmids encoding HPV16 and HPV18 E6/E7 antigens has been shown to generate robust immune responses in women with HPV-driven high-grade cervical dysplasia. We hypothesize that HPV-specific immunotherapy with INO-3112 (VGX-3100 + INO-9012) in patients with $\mathrm{HPV}$-associated HNSCCa will generate robust immunity which may contribute to disease stabilization or regression.

\section{Method}

Eligibility for this prospective Phase I/IIa trial included adults with HPV-positive (assessed by p16) HNSCCa, ECOG PS 0-1, and adequate organ function. Patients (pts) are enrolled into two cohorts. In Cohort 1, pts receive INO-3112 pre and post-surgery. In Cohort 2, pts receive INO-3112 after completion of cisplatin based chemoradiation. INO-3112 (6mg of VGX-3100 plus $1 \mathrm{mg}$ of INO-9012) is delivered IM followed by electroporation with the CELLECTRA ${ }^{\circledR}$ device, once every 3 weeks for a total of 4 doses. Pts are followed for 2 years. Primary and secondary endpoints are safety and immune responses.

'University of Pennsylvania, Philadelphia, PA, USA

Full list of author information is available at the end of the article
Exploratory endpoints include: anti-tumor effect and progression-free-survival. Assessment of post-immunotherapy surgical specimens is being done to evaluate vaccineinduced lymphocyte infiltration in tumor.

\section{Results}

As of June 2015, 19 pts have been enrolled. Complete safety data is available for 13 pts. Cohort $1: n=3$, Cohort 2: $\mathrm{n}=10 ; 12$ males; median age 57.7 years (range $39-76$ ); cancers at base of tongue $=6$, tonsil $=6$, soft palate $=1$; never smoker $=5$, median follow-up is 104 days. INO3112 was well tolerated with no Grade 3 or higher AEs. The most common AEs were injection site pain $(n=11)$, local erythema $(n=4)$ and hematoma/swelling $(n=2$, each). Two subjects had Grade 3 lymphopenia at baseline and no worsening during the trial. There was a Grade 2, unrelated SAE of post-surgical procedure hemorrhage. Enrollment and correlative analysis are ongoing; among samples tested to date, as compared to baseline, 4 of 5 evaluable pts showed elevated anti HPV16 and 18 E6/E7 antibody titers. Nine of 10 evaluable pts exhibited increased HPV-specific cellular responses by IFN-gamma ELISpot. Seven of 8 evaluable pts had HPV-specific CD8+ T cell activation concurrent with increased lytic proteins (granzymes and perforin) by flow cytometric analysis. 


\section{Conclusion}

These interim results demonstrate that this DNA-based immunotherapy (INO-3112) can safely generate HPVspecific CD8 $\mathrm{T}$ cell immunity in patients with HPVrelated HNSSCa. All tested pts had positive cellular immune responses in at least one assay.

This study (NCT02163057) is co-sponsored by Inovio and the Abramson Cancer Center at the University of Pennsylvania (5P30CA016520-39).

\section{Trial Registration}

ClinicalTrials.gov identifier NCT02163057.

\section{Authors' details}

'University of Pennsylvania, Philadelphia, PA, USA. ' Inovio Pharmaceuticals, Plymouth Meeting, PA, USA. ${ }^{3}$ Inovio Pharmaceuticals, San Diego, CA, USA. ${ }^{4}$ Inovio, Philadelphia, PA, USA. ${ }^{5}$ Inovio Pharmaceuticals, Inc., Plymouth Meeting, PA, USA.

Published: 4 November 2015

doi:10.1186/2051-1426-3-S2-P426

Cite this article as: Aggarwal et al:: Immunotherapy with VGX-3100 (HPV16 and HPV18 plasmids) + INO-9012 (DNA encoding IL-12) in human papillomavirus (HPV) associated head and neck squamous cell carcinoma (HNSCCa): interim safety and immunogenicity results. Journal for ImmunoTherapy of Cancer 2015 3(Suppl 2):P426.

Submit your next manuscript to BioMed Central and take full advantage of:

- Convenient online submission

- Thorough peer review

- No space constraints or color figure charges

- Immediate publication on acceptance

- Inclusion in PubMed, CAS, Scopus and Google Scholar

- Research which is freely available for redistribution

Submit your manuscript at www.biomedcentral.com/submit
C Biomed Central 